\title{
Pengaruh Pelayanan Perpustakaan Terhadap Prestasi Akademik Mahasiswa Fakultas Seni Rupa ISI Yogyakarta
}

\author{
Bandono $^{1}$, Susilowati ${ }^{2}$ \\ ${ }^{1,2}$ UPT Perpustakaan Institut Seni Indonesia Yogyakarta \\ Jalan Parangtritis km. 6,5 Yogyakarta \\ HP.: 08174120247; Email: bandono_1267@gmail.com
}

\begin{abstract}
Abstrak
Penelitian ini bertujuan untuk mengetahui pengaruh pelayanan perpustakaan terhadap prestasi akademik mahasiswa Fakultas Seni Rupa ISI Yogyakarta. Penelitian ini bersifat deskriptif dengan pendekatan kuantitatif. Cara analisis yang digunakan adalah analisis korelasional dengan pendekatan survei yang menggunakan kuesioner sebagai instrumen untuk pengumpulan data. Selain itu pengumpulan data didukung juga dengan dokumentasi. Tujuan penelitian ini adalah untuk mengetahui pengaruh pelayanan perpustakaan terhadap pestasi akademik mahasiswa Fakultas Seni Rupa ISI Yogyakarta. Teknik pengumpulan data adalah melalui kuesioner, studi pustaka, observasi dan dokumentasi. Teknik pengukuran variabel tentang pengaruh pelayanan menggunakan skala linkert. Dengan skala Linkert maka variabel akan diubah dan dijabarkan menjadi indikator variabel yang mana dalam penelitian ini ada 5 unsur (berdasarkan lima dimensi SerQual). Kelima dimensi tersebut merupakan satu kesatuan yang saling mendukung: (1) Tangibles; (2) Reliabilitas; (3) Responsivitas; (4) Jaminan; (5) Empati. Populasi dalam penelitian ini adalah pemustaka mahasiswa Fakultas Seni Rupa ISI Yogyakarta T.A 2018/2019. Populasi dalam penelitian ini adalah mahasiswa Fakultas Seni Rupa Institut Seni Indonesia Yogyakarta tahun angkatan 2018/2019 yang berjumlah 457 orang. Pengambilan sample dengan proportional sample atau sampel imbangan diperoleh sample sejumlah 64 mahasiswa. Secara keseluruhan dapat dilihat skor rata-rata tanggapan langsung mahasiswa terhadap pengaruh pelayanan perpustakaan terhadap prestasi akademik mahasiswa Fakultas Seni Rupa Institut Seni Indonesia Yogyakarta oleh pemustaka di UPT Perpustakaan Institut Seni Indonesia Yogyakarta adalah cenderung tinggi. Berdasarkan hasil dari pembahasan serta olah data tanggapan langsung responden serta dengan didukung data yang diperoleh dari Kasubag Pendidikan Fakultas Seni Rupa ISI Yogyakarta maka dapat disimpulkan bahwa terdapat pengaruh positif antara pelayanan UPT Perpustakaan ISI Yogyakarta dengan prestasi akademik mahasiswa Fakultas Seni Rupa Institut Seni Indonesia Yogyakarta.
\end{abstract}

Kata kunci: layanan; pemanfaatan perpustakaan; prestasi akademik

\begin{abstract}
The Influence of Library Services on Academic Achievement of Students of Faculty of Fine Arts ISI Yogyakarta. This research aims to find out the influence of library services on students' academic achievement of the Faculty of Fine Arts ISI Yogyakarta. This research is descriptive with a quantitative approach. The analysis is correlational analysis with a survey approach that uses questionnaires as intrusions for data collection. In addition, data collection is also supported by documentation. The purpose of this research is to find out the influence of library services on the academic party of students of the Faculty of Fine Arts ISI Yogyakarta. Data collection techniques are through questionnaires, library studies, observations and documentation variable measurement techniques on the effect of services using the Linkert scale. With the Linkert scale, the variable will be changed and spelt out into a variable indicator where in this study, there are 5 elements (based on the five dimensions of SerQual). The five dimensions are a unity that supports each other: (1) Tangibles; (2) Reliability; (3) Responsiveness; (4) Guarantee; (5) Empathy. The population in this study is the student library of the Faculty of Fine Arts ISI Yogyakarta T.A 2018/2019. The population in this
\end{abstract}


study was a student of the Faculty of Fine Arts, Yogyakarta Indonesian Institute of Art in 2018/2019, which amounted to 457 people. Sampling with proportional sample or balance sample obtained a selection of 64 students. Overall, it can be seen that the average score of students' direct responses to the influence of library services on the academic achievement of students of the Faculty of Fine Arts, ISI Yogyakarta, by the library at the library of the ISI Yogyakarta is likely to be high. Based on the results of the discussion and the processing of direct-response data of respondents and supported by data obtained from kasubag education, faculty of fine arts ISI Yogyakarta, it can be concluded that there is a positive influence between the services of ISI Yogyakarta Library and the academic achievement of students of the Faculty of Fine Arts, ISI Yogyakarta.

Keywords: service; library utilization; academic achievement

\section{A. Pendahuluan}

Perpustakaan dengan kegiatan pelayanan yang dilakukan merupakan bagian integral civitas perguruan tinggi yang turut menentukan kualitas prestasi akademik mahasiswanya. Selama ini belum pernah dilakukan penelitian pengaruh pelayanan perpustakaan terhadap prestasi akademik mahasiswanya di Fakultas Seni Rupa ISI Yogyakarta. Dalam penelitian ini dikaji pengaruh pelayanan perpustakaan terhadap prestasi akademik mahasiswa Fakultas Seni Rupa ISI Yogyakarta. Untuk mengetahui pengaruh pemanfaatan pelayanan terhadap prestasi akademik mahasiswa Fakultas Seni Rupa ISI Yogyakarta.

Fakultas Seni Rupa Institut Seni Indonesia Yogyakarta terdiri dari 4 jurusan yaitu; Seni Murni, Kriya, Desain, dan Tata Kelola Seni. Terbagi menjadi 8 program studi; Seni rupa murni, Kriya Seni, Desain interior, Disain Komunikasi Visual, Desain Produk, Tata kelola Seni, Batik dan fashion dan Kriya Kulit. Berdasar pada Pidato dan Laporan Rektor Pada Dies Natalis XXXV jumlah mahasiswa Fakultas Seni Rupa angkatan 2018/2019 sejumlah 457 mahasiswa.

Harapan pemerintah dan masyarakat dewasa ini semakin tinggi kepada perguruan tinggi, agar memberikan pendidikan kepada generasi penerus bangsa agar kreatif dan inovatif menuju pertumbuhan bidang pendidikan juga ekonomi. (Ismunandar: 2019). Hal tersebut tentu bukan hal yang dapat dipandang ringan. Namun dengan usaha yang sungguh-sungguh dengan memberikan pelayanan yang sesuai konsep pelayanan yang baik, pelayanan prima akan bisa diwujudkan. Dalam memberikan layanannya perpustakaan harus dapat memberikan layanan yang cepat, tepat dan benar. Hal ini perlu diperhatikan karena berpengaruh terhadap kepuasan pemustaka. Tingkat kepuasan pemustaka terhadap layanan perpustakaan dapat dirasakan oleh pemustaka jika yang menjadi harapan dari pemustaka dapat terpenuhi atau bahkan melebihi dari harapan awalnya (Agustiawan, 2018: 2).

UPT Perpustakaan ISI Yogyakarta mempunyai beberapa pelayanan yang disediakan. Pelayananpelayanan tersebut antara lain seperti pelayanan pendidikan pemakai, pelayanan peminjaman bahan pustaka, pelayanan referensi, pelayanan terbitan berkala, pelayanan koleksi karya ilmiah dan laporan penelitian, layanan fotocopy, dan layanan pandang dengar (Agustiawan dan Bandono, 2021: 10-12). Sebagai lembaga yang bergerak pada bidang layanan jasa informasi bagi sivitas akademika tentu tidaklah mudah dilakukan agar pelayanan yang dilakukan mampu memberikan kontribusi yang baik dalam pengertian berperan positif terhadap prestasi akademik mahasiswanya. Untuk itu diperlukan perencanaan, persiapan yang matang, serta pelaksanaan yang mengacu kepuasan pemustaka sehingga pelayanan yang dijalankan benar-benar mampu memberikan hasil positif terhadap prestasi akademik mahasiswanya.

\section{B. Metode Penelitian}

Peneltian ini bersifat deskriptif dengan pendekatan kuantitatif. Cara analisis yang digunakan 
adalah analisis korelasional dengan pendekatan survei yang menggunakan kuesioner sebagai intrumen untuk pengumpulan data.

Selain itu pengumpulan data didukung juga dengan dokumentasi. Dalam penelitian ini peneliti menggunakan pendekatan kuantitatif dengan dilengkapi metode wawancara dengan kuesioner yang disampaikan kepada para responden menggunakan Skala Likert yang merupakan salah satu cara menentukan skor. Kuesioner digunakan untuk mendapatkan jawaban responden terhadap pertanyaan mengenai pengaruh pelayanan perpustakaan terhadap prestasi akademik mahasiswa Fakultas Seni Rupa ISI Yogyakarta. Kriteria penilaian digolongkan dalam 4 tingkatan, dengan penilaian sebagai berikut:

1. Jawaban Sangat Setuju (SS) diberi nilai 4.

2. Jawaban Setuju (S) diberi nilai 3.

3. Jawaban Tidak Setuju (TS) diberi nilai 2.

4. Jawaban Sangat Tidak Setuju (STS) diberi nilai 1.

Menurut Vredenbergt dalam Martaningsih (2007: 45) yang dikutip oleh Titik Rohayati (2008) dinyatakan bahwa untuk memperoleh jumlah skor, setiap kemungkinan jawaban dikalikan dengan nilai yang telah ditetapkan. Jumlah perkalian tersebut kemudian dibagi dengan jumlah kuesioner yang diolah untuk memperoleh nilai rata-rata. Berdasarkan nilai rata-rata tersebut maka tanggapan langsung dan sikap responden terhadap pengaruh pelayanan perpustakaan terhadap prestasi akademik mahasiswa Fakultas Seni Rupa ISI Yogyakarta dapat diketahui pada tabel 1 .

\section{Hasil dan Pembahasan}

Untuk mengetahui pengaruh pelayanan perpustakaan terhadap prestasi akademik mahasiswa Fakultas Seni Rupa Institut Seni Indonesia

Tabel 1. Kategori sikap responden berdasar nilai rata-rata.

\begin{tabular}{ll}
\hline \multicolumn{1}{c}{ Kategori } & Nilai Rata-rata \\
\hline Sangat Tinggi & 4,34 s.d. 5,00 \\
Tinggi & 3,67 s.d. 4,33 \\
Cenderung Tinggi & 3,01 s.d. 3,66 \\
Cenderung Rendah & 2,34 s.d. 3,00 \\
Rendah & 1,67 s.d. 2,33 \\
Sangat Rendah & 1,00 s.d. 1,66 \\
\hline
\end{tabular}

Yogyakarta, penulis melakukan penyebaran kuisioner secara online kepada 64 mahasiswa mewakili angkatan tahun 2018/2019. Mahasiswa tersebut terdaftar sebagai mahasiswa Fakultas Seni Rupa Institut Seni Indonesia Yogyakarta.

Hasil pengolahan data dari pernyataan nomor satu yaitu mengenai responden mengetahui adanya pelayanan di Perpustakaan Institut Seni Indonesia Yogyakarta. Ada 62,50\% responden dengan jumlah 40 mahasiswa sangat setuju mereka mengetahui adanya pelayanan di UPT Perpustakan Institut Seni Indonesia Yogyakarta. Sedangkan yang menjawab setuju mereka mengetahui adanya pelayanan di UPT Perpustakaan ISI Yogyakarta sebesar 37,50\% dengan jumlah mahasiswa sejumlah 24 mahasiswa. Selanjutnya tidak seorangpun yang menjawab tidak setuju dan sangat tidak setuju bahwa mereka mengetahui adanya pelayanan di UPT Perpustakaan Institut Seni Indonesia Yogyakarta. Dari data tersebut peneliti menyimpulkan bahwa mayoritas mahasiswa setuju dengan pernyataan bahwa mereka mengetahui adanya pelayanan di UPT Perpustakaan Institut Seni Indonesia Yogyakarta. Selanjutnya berdasarkan skor ratarata dengan nilai 3,63 dapat disimpulkan bahwa tanggapan langsung responden atau mahasiswa yang mengetahui adanya pelayanan di UPT Perpustakaan ISI Yogyakarta cenderung tinggi.

Hasil pengolahan data dari pernyataan nomor dua yaitu mengenai frekuensi sering memanfaatkan pelayanan yang ada di Perpustakaan Institut Seni Indonesia Yogyakarta. Dari data yang ada 31,25\% responden dengan jumlah 20 mahasiswa sangat setuju mereka sering memanfaatkan pelayanan yang ada di UPT Perpustakan Institut Seni Indonesia Yogyakarta. Sedangkan yang menjawab setuju mereka sering memanfaatkan pelayanan yang ada di UPT Perpustakaan ISI Yogyakarta sebesar 54,69\% dengan jumlah mahasiswa sejumlah 35 mahasiswa. Selanjutnya yang memilih jawaban tidak setuju mereka sering memanfaatkan pelayanan yang ada di UPT Perpustakan Institut Seni Indonesia Yogyakarta sebesar $14,06 \%$ dengan jumlah mahasiswa sejumlah 9 mahasiswa. Sedangkan yang memilih jawaban sangat tidak setuju bahwa mereka mereka sering memanfaatkan pelayanan yang ada pelayanan di UPT Perpustakaan Institut 
Seni Indonesia Yogyakarta sama sekali tidak ada. Dari data tersebut peneliti menyimpulkan bahwa mayoritas mahasiswa setuju dengan pernyataan bahwa mereka mereka sering memanfaatkan pelayanan yang ada pelayanan di UPT Perpustakaan Institut Seni Indonesia Yogyakarta.

Selanjutnya berdasarkan skor rata-rata diperoleh hasil 3,17 sehingga dapat disimpulkan bahwa tanggapan langsung responden atau mahasiswa yang mereka sering memanfaatkan pelayanan yang ada di UPT Perpustakaan ISI Yogyakarta cenderung tinggi.

Hasil pengolahan data dari pernyataan nomor tiga yaitu mengenai pernyataan bahwa pelayanan yang ada di Perpustakaan Institut Seni Indonesia Yogyakarta memudahkan mahasiswa mendapatkan informasi yang dibutuhkan. Data yang diperoleh menunjukkan bahwa 34,38\% responden dengan jumlah 22 mahasiswa memilih jawaban sangat setuju, bahwa pelayanan di UPT Perpustakan Institut Seni Indonesia Yogyakarta memudahkannya mendapatkan informasi yang dibutuhkannya. Sedangkan yang memilih jawaban setuju bahwa pelayanan yang ada di UPT Perpustakaan Institut Seni Indonesia Yogyakarta memudahkan mahasiswa mendapatkan informasi yang dibutuhkan sebesar 60,94\% dengan jumlah mahasiswa sejumlah 39 mahasiswa. Selanjutnya yang memilih jawaban tidak setuju mereka bahwa pelayanan yang ada di UPT Perpustakaan Institut Seni Indonesia Yogyakarta memudahkan mahasiswa mendapatkan informasi yang dibutuhkan sebesar 4,69\% dengan jumlah mahasiswa sejumlah 3 mahasiswa. Sedangkan yang memilih jawaban sangat tidak setuju bahwa pelayanan yang ada di UPT Perpustakaan Institut Seni Indonesia Yogyakarta memudahkan mahasiswa mendapatkan informasi yang dibutuhkan sama sekali tidak ada. Dari data tersebut peneliti menyimpulkan bahwa mayoritas mahasiswa setuju dengan pernyataan bahwa pelayanan yang ada di UPT Perpustakaan Institut Seni Indonesia Yogyakarta memudahkan mahasiswa mendapatkan informasi yang dibutuhkan.

Selanjutnya berdasarkan skor rata-rata diperoleh data 3,30 sehingga dapat disimpulkan bahwa tanggapan langsung responden atau mahasiswa yang menyatakan bahwa pelayanan yang ada di UPT Perpustakaan Institut Seni Indonesia Yogyakarta memudahkan mahasiswa mendapatkan informasi yang dibutuhkan cenderung tinggi.

Hasil pengolahan data dari pernyataan nomor empat yaitu mengenai pernyataan bahwa pelayanan di UPT Perpustakaan Institut Seni Indonesia Yogyakarta koleksinya lengkap dan up to date. Tabel 1 menunjukkan bahwa 4,69\% responden dengan jumlah 3 mahasiswa memilih jawaban sangat setuju, bahwa pelayanan di UPT Perpustakaan Institut Seni Indonesia Yogyakarta koleksinya lengkap dan up to date. Sedangkan yang memilih jawaban setuju bahwa pelayanan di Perpustakaan Institut Seni Indonesia Yogyakarta koleksinya lengkap dan up to date sebesar 68,75\% dengan jumlah mahasiswa sejumlah 44 mahasiswa. Selanjutnya yang memilih jawaban tidak setuju mereka bahwa pelayanan di UPT Perpustakaan Institut Seni Indonesia Yogyakarta koleksinya lengkap dan up to date sebesar $26,56 \%$ dengan jumlah mahasiswa sejumlah 17 mahasiswa. Sedangkan yang memilih jawaban sangat tidak setuju bahwa pelayanan di UPT Perpustakaan Institut Seni Indonesia Yogyakarta koleksinya lengkap dan up to date sama sekali tidak ada. Dari data tersebut peneliti menyimpulkan bahwa mayoritas mahasiswa setuju dengan pernyataan bahwa pelayanan di UPT Perpustakaan Institut Seni Indonesia Yogyakarta koleksinya lengkap dan up to date.

Selanjutnya berdasarkan skor rata-rata diperoleh data 2,78 sehingga dapat disimpulkan bahwa tanggapan langsung responden atau mahasiswa yang menyatakan bahwa pelayanan di UPT Perpustakaan Institut Seni Indonesia Yogyakarta koleksinya lengkap dan up to date cenderung rendah.

Hasil pengolahan data dari pernyataan nomor lima yaitu mengenai pernyataan bahwa mahasiswa merasa cukup puas atas pelayanan di UPT Perpustakaan ISI Yogyakarta. Tabel diatas menunjukkan bahwa 15,63\% responden dengan jumlah 10 mahasiswa memilih jawaban sangat setuju, bahwa mahasiswa merasa cukup puas atas pelayanan di UPT Perpustakaan ISI Yogyakarta. Sedangkan yang memilih jawaban setuju bahwa 
mahasiswa merasa cukup puas atas pelayanan di UPT Perpustakaan ISI Yogyakarta sebesar 71,88\% dengan jumlah mahasiswa sejumlah 46 mahasiswa. Selanjutnya yang memilih jawaban tidak setuju mereka bahwa mahasiswa merasa cukup puas atas pelayanan di UPT Perpustakaan ISI Yogyakarta sebesar $12,50 \%$ dengan jumlah mahasiswa sejumlah 8 mahasiswa. Sedangkan yang memilih jawaban sangat tidak setuju bahwa mahasiswa merasa cukup puas atas pelayanan di UPT Perpustakaan ISI Yogyakarta sama sekali tidak ada. Dari data tersebut peneliti menyimpulkan bahwa mayoritas mahasiswa setuju dengan pernyataan bahwa mahasiswa merasa cukup puas atas pelayanan di UPT Perpustakaan ISI Yogyakarta.

Selanjutnya berdasarkan skor rata-rata diperoleh data 3,03 sehingga dapat disimpulkan bahwa tanggapan langsung responden atau mahasiswa yang menyatakan bahwa mahasiswa merasa cukup puas atas pelayanan di UPT Perpustakaan ISI Yogyakarta cenderung tinggi.

Hasil pengolahan data dari pernyataan nomor enam yaitu mengenai pernyataan bahwa mahasiswa menjadikan pelayanan di UPT Perpustakaan ISI Yogyakarta sebagai langkah utama mendapatkan informasi yang saya butuhkan. Hal ini menunjukkan bahwa 25,00\% responden dengan jumlah 16 mahasiswa memilih jawaban sangat setuju, bahwa mahasiswa menjadikan pelayanan di UPT Perpustakaan ISI Yogyakarta sebagai langkah utama mendapatkan informasi yang saya butuhkan. Sedangkan yang memilih jawaban setuju bahwa mahasiswa menjadikan pelayanan di UPT Perpustakaan ISI Yogyakarta sebagai langkah utama mendapatkan informasi yang saya butuhkan sebesar 50,00\% dengan jumlah mahasiswa sejumlah 32 mahasiswa. Selanjutnya yang memilih jawaban tidak setuju mereka bahwa mahasiswa menjadikan pelayanan di UPT Perpustakaan ISI Yogyakarta sebagai langkah utama mendapatkan informasi yang saya butuhkan sebesar 25,00\% dengan jumlah mahasiswa sejumlah 16 mahasiswa. Sedangkan yang memilih jawaban sangat tidak setuju bahwa mahasiswa menjadikan pelayanan di UPT Perpustakaan ISI Yogyakarta sebagai langkah utama mendapatkan informasi yang saya butuhkan sama sekali tidak ada. Dari data tersebut peneliti menyimpulkan bahwa mayoritas mahasiswa setuju dengan pernyataan bahwa mahasiswa merasa cukup puas atas pelayanan di UPT Perpustakaan ISI Yogyakarta.

Selanjutnya berdasarkan skor rata-rata diperoleh nilai 3,00 sehingga dapat disimpulkan bahwa tanggapan langsung responden atau mahasiswa yang menyatakan bahwa mahasiswa menjadikan pelayanan di UPT Perpustakaan ISI Yogyakarta sebagai langkah utama mendapatkan informasi yang saya butuhkan cenderung rendah. Hasil pengolahan data dari pernyataan nomor tujuh yaitu mengenai pernyataan bahwa mahasiswa tidak pernah membaca koleksi-koleksi yang ada di UPT Perpustakaan ISI Yogyakarta. Data yang ada menunjukkan bahwa 3,13\% responden dengan jumlah 2 mahasiswa memilih jawaban sangat setuju, bahwa mahasiswa tidak pernah membaca koleksi-koleksi yang ada di UPT Perpustakaan ISI Yogyakarta. Sedangkan yang memilih jawaban setuju bahwa mahasiswa tidak pernah membaca koleksi-koleksi yang ada di UPT Perpustakaan ISI Yogyakarta sebesar 20,31\% dengan jumlah mahasiswa sejumlah 13 mahasiswa. Selanjutnya yang memilih jawaban tidak setuju mereka bahwa mahasiswa tidak pernah membaca koleksi-koleksi yang ada di UPT Perpustakaan ISI Yogyakarta sebesar 50,00\% dengan jumlah mahasiswa sejumlah 32 mahasiswa. Sedangkan yang memilih jawaban sangat tidak setuju bahwa mahasiswa tidak pernah membaca koleksi-koleksi yang ada di UPT Perpustakaan ISI Yogyakarta sejumlah 26,56 dengan jumlah mahasiswa sejumlah 17 mahasiswa. Dari data tersebut peneliti menyimpulkan bahwa mayoritas mahasiswa tidak setuju dengan pernyataan bahwa mahasiswa tidak pernah membaca koleksi-koleksi yang ada di Perpustakaan ISI Yogyakarta

Selanjutnya berdasarkan skor rata-rata diperoleh data 2,00 sehingga dapat disimpulkan bahwa tanggapan langsung responden atau mahasiswa yang menyatakan bahwa mahasiswa tidak pernah membaca koleksi-koleksi yang ada di UPT Perpustakaan ISI Yogyakarta rendah.

Hasil pengolahan data dari pernyataan nomor delapan yaitu mengenai pernyataan bahwa mahasiswa sering memanfaatkan pelayanan di UPT 
Perpustakaan ISI Yogyakarta untuk mengerjakan tugas yang diberikan oleh pengajar untuk meningkatkan prestasi belajarnya. Data yang ada menunjukkan bahwa 32,81\% responden dengan jumlah 21 mahasiswa memilih jawaban sangat setuju, bahwa mahasiswa sering memanfaatkan pelayanan di UPT Perpustakaan ISI Yogyakarta untuk mengerjakan tugas yang diberikan oleh pengajar untuk meningkatkan prestasi belajarnya. Sedangkan yang memilih jawaban setuju bahwa mahasiswa sering memanfaatkan pelayanan di UPT Perpustakaan ISI Yogyakarta untuk mengerjakan tugas yang diberikan oleh pengajar untuk meningkatkan prestasi belajarnya.sebesar 48,44\% dengan jumlah mahasiswa sejumlah 31 mahasiswa. Selanjutnya yang memilih jawaban tidak setuju mereka bahwa mahasiswa sering memanfaatkan pelayanan di UPT Perpustakaan ISI Yogyakarta untuk mengerjakan tugas yang diberikan oleh pengajar untuk meningkatkan prestasi belajarnya sebesar $17,19 \%$ dengan jumlah mahasiswa sejumlah 11 mahasiswa. Sedangkan yang memilih jawaban sangat tidak setuju bahwa mahasiswa sering memanfaatkan pelayanan di UPT Perpustakaan ISI Yogyakarta untuk mengerjakan tugas yang diberikan oleh pengajar untuk meningkatkan prestasi belajarnya sejumlah 1,56 dengan jumlah mahasiswa sejumlah 1 mahasiswa. Dari data tersebut peneliti menyimpulkan bahwa mayoritas mahasiswa setuju dengan pernyataan bahwa mahasiswa sering memanfaatkan pelayanan di UPT Perpustakaan ISI Yogyakarta untuk mengerjakan tugas yang diberikan oleh pengajar untuk meningkatkan prestasi belajarnya.

Selanjutnya berdasarkan skor rata-rata diperoleh data 3,13 sehingga dapat disimpulkan bahwa tanggapan langsung responden atau mahasiswa yang menyatakan bahwa mahasiswa tidak pernah membaca koleksi-koleksi yang ada di UPT Perpustakaan ISI Yogyakarta cenderung tinggi.

Hasil pengolahan data dari pernyataan nomor sembilan yaitu mengenai pernyataan bahwa dengan pelayanan UPT Perpustakaan ISI Yogyakarta yang diberikan dapat membantu saya meningkatkan prestasi akademik saya di kelas. Data yang diperoleh menunjukkan bahwa 17,19\% responden dengan jumlah 11 mahasiswa memilih jawaban sangat setuju, bahwa dengan pelayanan UPT Perpustakaan ISI Yogyakarta yang diberikan dapat membantu saya meningkatkan prestasi akademiknya di kelas. Sedangkan yang memilih jawaban setuju bahwa dengan pelayanan UPT Perpustakaan ISI Yogyakarta yang diberikan dapat membantu saya meningkatkan prestasi akademik saya di kelas sebesar $76,56 \%$ dengan jumlah mahasiswa sejumlah 49 mahasiswa. Selanjutnya yang memilih jawaban tidak setuju mereka dengan pelayanan UPT Perpustakaan ISI Yogyakarta yang diberikan dapat membantu saya meningkatkan prestasi akademiknya di kelas sebesar 6,25\% dengan jumlah mahasiswa sejumlah 4 mahasiswa. Sedangkan yang memilih jawaban sangat tidak setuju bahwa dengan pelayanan UPT Perpustakaan ISI Yogyakarta yang diberikan dapat membantu saya meningkatkan prestasi akademik saya di kelas sama sekali tidak ada. Dari data tersebut peneliti menyimpulkan bahwa mayoritas mahasiswa setuju dengan pernyataan dengan pelayanan UPT Perpustakaan ISI Yogyakarta yang diberikan dapat membantu saya meningkatkan prestasi akademik saya di kelas.

Selanjutnya berdasarkan skor rata-rata diperoleh 3,11 sehingga dapat disimpulkan bahwa tanggapan langsung responden atau mahasiswa yang menyatakan bahwa mahasiswa tidak pernah membaca koleksi-koleksi yang ada di UPT Perpustakaan ISI Yogyakarta cenderung tinggi.

Hasil pengolahan data dari pernyataan nomor sepuluh yaitu mengenai pernyataan bahwa pelayanan perpustakaan yang dilaksanakan membantu saya dalam mengakses dan membaca koleksi yang ada di UPT Perpustakaan ISI Yogyakarta menunjukkan bahwa 20,31\% responden dengan jumlah 13 mahasiswa memilih jawaban sangat setuju, bahwa pelayanan perpustakaan yang dilaksanakan membantu saya dalam mengakses dan membaca koleksi yang ada di UPT Perpustakaan ISI Yogyakarta. Sedangkan yang memilih jawaban setuju bahwa pelayanan Perpustakaan yang dilaksanakan membantu saya dalam mengakses dan membaca koleksi yang ada di UPT Perpustakaan ISI Yogyakarta sebesar 78,13\% dengan jumlah mahasiswa sejumlah 50 mahasiswa. Selanjutnya yang memilih jawaban tidak setuju 
mereka dengan pelayanan perpustakaan yang dilaksanakan membantu saya dalam mengakses dan membaca koleksi yang ada di UPT Perpustakaan ISI Yogyakarta sebesar 1,56\% dengan jumlah mahasiswa sejumlah 1 mahasiswa. Sedangkan yang memilih jawaban sangat tidak setuju bahwa pelayanan perpustakaan yang dilaksanakan membantu saya dalam mengakses dan membaca koleksi yang ada di UPT Perpustakaan ISI Yogyakarta sama sekali tidak ada. Dari data tersebut peneliti menyimpulkan bahwa mayoritas mahasiswa setuju dengan pernyataan dengan pelayanan perpustakaan yang dilaksanakan membantu saya dalam mengakses dan membaca koleksi yang ada di UPT Perpustakaan ISI Yogyakarta.

Berdasarkan skor rata-rata diperoleh data 3,19 sehingga dapat disimpulkan bahwa tanggapan langsung responden atau mahasiswa yang menyatakan bahwa pelayanan Perpustakaan yang dilaksanakan membantu saya dalam mengakses dan membaca koleksi yang ada di UPT Perpustakaan ISI Yogyakarta. cenderung tinggi.

Hasil pengolahan data dari pernyataan nomor sebelas yaitu mengenai pernyataan bahwa pelayanan UPT Perpustakaan ISI Yogyakarta membantu saya mendapatkan nilai baik setelah saya mencari bahan bacaan untuk belajar di dalamnya. Data yang ada menunjukkan bahwa 9,38\% responden dengan jumlah 6 mahasiswa memilih jawaban sangat setuju, bahwa pelayanan UPT Perpustakaan ISI Yogyakarta membantu saya mendapatkan nilai baik setelah saya mencari bahan bacaan untuk belajar di dalamnya. Sedangkan yang memilih jawaban setuju bahwa pelayanan UPT Perpustakaan ISI Yogyakarta membantu saya mendapatkan nilai baik setelah saya mencari bahan bacaan untuk belajar di dalamnya sebesar $73,44 \%$ dengan jumlah mahasiswa sejumlah 47 mahasiswa. Selanjutnya yang memilih jawaban tidak setuju mereka dengan pelayanan UPT Perpustakaan ISI Yogyakarta membantu saya mendapatkan nilai baik setelah saya mencari bahan bacaan untuk belajar di dalamnya sebesar $17,19 \%$ dengan jumlah mahasiswa sejumlah 11 mahasiswa. Sedangkan yang memilih jawaban sangat tidak setuju bahwa pelayanan UPT Perpustakaan ISI Yogyakarta membantu saya mendapatkan nilai baik setelah saya mencari bahan bacaan untuk belajar di dalamnya sama sekali tidak ada. Dari data tersebut peneliti menyimpulkan bahwa mayoritas mahasiswa setuju dengan pernyataan dengan pelayanan UPT Perpustakaan ISI Yogyakarta membantu saya mendapatkan nilai baik setelah saya mencari bahan bacaan untuk belajar di dalamnya.

Selanjutnya berdasarkan skor rata-rata diperoleh data 2,92 sehingga dapat disimpulkan bahwa tanggapan langsung responden atau mahasiswa yang menyatakan bahwa pelayanan UPT Perpustakaan ISI Yogyakarta membantu saya mendapatkan nilai baik setelah saya mencari bahan bacaan untuk belajar di dalamnya cenderung rendah.

Hasil pengolahan data dari pernyataan nomor dua belas yaitu mengenai pernyataan bahwa pelayanan UPT Perpustakaan ISI Yogyakarta membantu saya untuk meningkatkan nilai harian, tengah semester, dan akhir semester saya. Data yang ada menunjukkan bahwa 9,38\% responden dengan jumlah 6 mahasiswa memilih jawaban sangat setuju, bahwa pelayanan UPT Perpustakaan ISI Yogyakarta membantu saya untuk meningkatkan nilai harian, tengah semester, dan akhir semester saya. Sedangkan yang memilih jawaban setuju bahwa pelayanan UPT Perpustakaan ISI Yogyakarta membantu saya untuk meningkatkan nilai harian, tengah semester, dan akhir semester saya sebesar $70,31 \%$ dengan jumlah mahasiswa sejumlah 45 mahasiswa. Yang memilih jawaban tidak setuju dengan pelayanan UPT Perpustakaan ISI Yogyakarta membantu saya untuk meningkatkan nilai harian, tengah semester, dan akhir semester saya sebesar 20,31\% dengan jumlah mahasiswa sejumlah 13 mahasiswa. Sedangkan yang memilih jawaban sangat tidak setuju bahwa pelayanan UPT Perpustakaan ISI Yogyakarta membantu saya untuk meningkatkan nilai harian, tengah semester, dan akhir semester saya sama sekali tidak ada. Dari data tersebut peneliti menyimpulkan bahwa mayoritas mahasiswa setuju dengan pernyataan dengan pelayanan UPT Perpustakaan ISI Yogyakarta membantu saya untuk meningkatkan nilai harian, tengah semester, dan akhir semester saya.

Selanjutnya berdasarkan skor rata-rata diperoleh hasil 2,89 sehingga dapat disimpulkan 
bahwa tanggapan langsung responden atau mahasiswa yang menyatakan bahwa pelayanan UPT Perpustakaan ISI Yogyakarta membantu saya mendapatkan nilai baik setelah saya mencari bahan bacaan untuk belajar di dalamnya cenderung rendah.

Hasil pengolahan data dari pernyataan nomor tiga belas yaitu mengenai pernyataan bahwa mahasiswa tidak pernah ke UPT Perpustakaan ISI Yogyakarta untuk memenuhi kebutuhan informasi belajar saya. Data yang ada menunjukkan bahwa $3,13 \%$ responden dengan jumlah 2 mahasiswa memilih jawaban sangat setuju, bahwa mahasiswa tidak pernah ke UPT Perpustakaan ISI Yogyakarta untuk memenuhi kebutuhan informasi belajar saya Sedangkan yang memilih jawaban setuju bahwa mahasiswa tidak pernah ke UPT Perpustakaan ISI Yogyakarta untuk memenuhi kebutuhan informasi belajarnya sebesar $18,75 \%$ dengan jumlah mahasiswa sejumlah 12 mahasiswa. Selanjutnya yang memilih jawaban tidak setuju mereka mahasiswa tidak pernah ke UPT Perpustakaan ISI Yogyakarta untuk memenuhi kebutuhan informasi belajar saya sebesar $32,81 \%$ dengan jumlah mahasiswa sejumlah 21 mahasiswa. Sedangkan yang memilih jawaban sangat tidak setuju bahwa mahasiswa tidak pernah ke UPT Perpustakaan ISI Yogyakarta untuk memenuhi kebutuhan informasi belajar saya sebesar $45,31 \%$ denagn jumlah 29 mahasiswa. Dari data tersebut peneliti menyimpulkan bahwa mayoritas mahasiswa tidak setuju dengan pernyataan mahasiswa tidak pernah ke UPT Perpustakaan ISI Yogyakarta untuk memenuhi kebutuhan informasi belajar saya

Selanjutnya berdasarkan skor rata-rata yang dipeoleh 1,80 dapat disimpulkan bahwa tanggapan langsung responden atau mahasiswa yang menyatakan bahwa mahasiswa tidak pernah ke UPT Perpustakaan ISI Yogyakarta untuk memenuhi kebutuhan informasi belajar saya rendah.

Hasil pengolahan data dari pernyataan nomor empat belas yaitu mengenai pernyataan bahwa mahasiswa sering membaca koleksi buku, jurnal, majalah yang ada di UPT Perpustakaan ISI Yogyakarta untuk meningkatkan pengetahuan dan prestasi akademik saya di kelas bahwa 3,13\% responden dengan jumlah 2 mahasiswa memilih jawaban sangat setuju, bahwa mahasiswa sering membaca koleksi buku, jurnal, majalah yang ada di UPT Perpustakaan ISI Yogyakarta untuk meningkatkan pengetahuan dan prestasi akademik saya di kelas. Sedangkan yang memilih jawaban setuju bahwa mahasiswa sering membaca koleksi buku, jurnal, majalah yang ada di UPT Perpustakaan ISI Yogyakarta untuk meningkatkan pengetahuan dan prestasi akademik saya di kelas sebesar 79,69\% dengan jumlah mahasiswa sejumlah 51 mahasiswa. Selanjutnya yang memilih jawaban tidak setuju mereka mahasiswa sering membaca koleksi buku, jurnal, majalah yang ada di UPT Perpustakaan ISI Yogyakarta untuk meningkatkan pengetahuan dan prestasi akademik saya di kelas sebesar 15,63\% dengan jumlah mahasiswa sejumlah 10 mahasiswa. Sedangkan yang memilih jawaban sangat tidak setuju bahwa mahasiswa sering membaca koleksi buku, jurnal, majalah yang ada di Perpustakaan ISI Yogyakarta untuk meningkatkan pengetahuan dan prestasi akademik saya di kelas sebesar 1,56\% denagn jumlah 1 mahasiswa. Dari data tersebut peneliti menyimpulkan bahwa mayoritas mahasiswa setuju dengan pernyataan mahasiswa sering membaca koleksi buku, jurnal, majalah yang ada di Perpustakaan ISI Yogyakarta untuk meningkatkan pengetahuan dan prestasi akademik saya di kelas. Selanjutnya berdasarkan skor ratarata pada tabel $4.14=(2,84)$ dapat disimpulkan bahwa tanggapan langsung responden atau mahasiswa yang menyatakan bahwa mahasiswa sering membaca koleksi buku, jurnal, majalah yang ada di UPT Perpustakaan ISI Yogyakarta untuk meningkatkan pengetahuan dan prestasi akademik saya di kelas cenderung rendah.

Hasil pengolahan data dari pernyataan nomor lima belas yaitu mengenai pernyataan bahwa mahasiswa merasa pelayanan di UPT Perpustakaan ISI Yogyakarta mampu meningkatkan prestasi akademik saya selama menempuh pendidikan bahwa $12,50 \%$ responden dengan jumlah 8 mahasiswa memilih jawaban sangat setuju, bahwa mahasiswa merasa pelayanan di UPT Perpustakaan ISI Yogyakarta mampu meningkatkan prestasi akademiknya selama menempuh pendidikan. Sedangkan yang memilih jawaban setuju bahwa 
merasa pelayanan di UPT Perpustakaan ISI Yogyakarta mampu meningkatkan prestasi akademik saya selama menempuh pendidikan sebesar 79,69\% dengan jumlah mahasiswa sejumlah 51 mahasiswa. Selanjutnya yang memilih jawaban tidak setuju mereka mahasiswa merasa pelayanan di UPT Perpustakaan ISI Yogyakarta mampu meningkatkan prestasi akademik saya selama menempuh pendidikan sebesar 6,25\% dengan jumlah mahasiswa sejumlah 4 mahasiswa. Sedangkan yang memilih jawaban sangat tidak setuju bahwa merasa pelayanan di UPT Perpustakaan ISI Yogyakarta mampu meningkatkan prestasi akademik saya selama menempuh pendidikan sebesar $1,56 \%$ denagn jumlah 1 mahasiswa. Dari data tersebut peneliti menyimpulkan bahwa mayoritas mahasiswa setuju dengan pernyataan merasa pelayanan di UPT Perpustakaan ISI Yogyakarta mampu meningkatkan prestasi akademik mahasiswa selama menempuh pendidikan.

Selanjutnya berdasarkan skor rata-rata diperoleh nilai 3,03 sehingga dapat disimpulkan bahwa tanggapan langsung responden atau mahasiswa yang menyatakan bahwa merasa pelayanan di UPT Perpustakaan ISI Yogyakarta mampu meningkatkan prestasi akademik saya selama menempuh pendidikan cenderung tinggi.

Berdasarkan data dan informasi yang penulis peroleh dari Kasubbag Pendidikan dan Kemahasiswaan Fakultas Seni Rupa Institut Seni Indonesia Yogyakarta, beliau Bapak Aji Purnama, S.T. menyampaikan bahwa rerata Indek Prestasi mahasiswa Fakultas Seni Rupa Institut Seni Indonesia Yogyakarta dari semester 1 hingga semester ke 3 mengalami kenaikan. Rerata untuk semester 4 belum bisa dihitung reratannya karena pada saat permohonan data Indeks Prestasi

Tabel 2. Tabel indeks prestasi akademik hasil studi semester mahasiswa FSR ISI Yogyakarta angkatan 2018/2019.

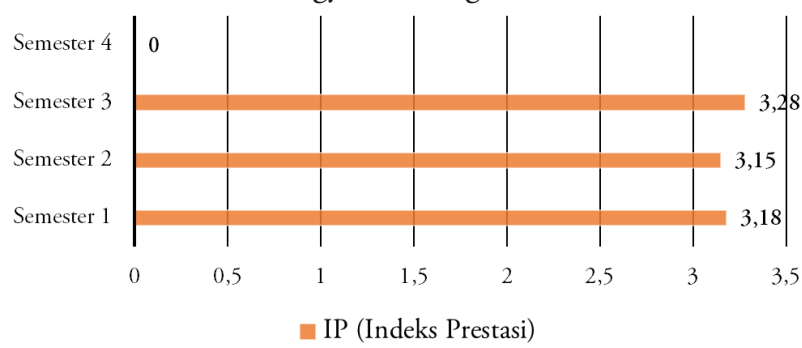

disampaikan nilai belum masuk. Adapun data dan informasi seperti terlampir pada tabel 2 .

\section{Kesimpulan dan Saran}

Berdasarkan hasil dari pembahasan serta olah data tanggapan langsung responden atau mahasiswa Fakultas Seni Rupa ISI Yogyakarta terhadap pengaruh pelayanan UPT Perpustakaan ISI Yogyakarta terhadap prestasi akademik mahasiswa Fakultas Seni Rupa Institut Seni Indonesia Yogyakarta adalah cenderung tinggi. Selanjutnya juga atas dukungan data informasi dari Kasubag Pendidikan FSR ISI Yogyakarta yang menyatakan bahwa rerata IP (Indek Prestasi) mahasiswa Fakultas Seni Rupa Institut Seni Indonesia Yogyakarta angkatan 2018/2019 dari semester ke semester ke berikutnya mengalami kenaikan. Berdasarkan hasil dari pembahasan serta olah data tanggapan langsung responden serta dengan didukung data yang diperoleh dari Kasubag Pendidikan Fakultas Seni Rupa ISI Yogyakarta maka dapat penulis simpulkan bahwa terdapat pengaruh positif antara pelayanan UPT Perpustakaan ISI Yogyakarta dengan prestasi akademik mahasiswa Fakultas Seni Rupa Institut Seni Indonesia Yogyakarta.

\section{Kepustakaan}

Agustiawan. 2018. Evaluasi Kualitas Layanan UPT Perpustakaan ISI Yogyakarta Berdasarkan Pedoman Survei Kepuasan Masyarakat Terhadap Penyelenggaraan Pelayanan Publik. Yogyakarta: Lembaga Penelitian Institut Seni Indonesia Yogyakarta.

Agustiawan, Bandono. 2021. Buku Panduan UPT Perpustakaan ISI Yogyakarta. Yogyakarta: UPT Perpustakaan ISI Yogyakarta.

Dewi, Meutia. 2015. Pengaruh Kualitas Pelayanan dan Fasilitas Perpustakaan terhadap Prestasi Belajar Mahasiswa Universitas Samudra. Aceh: Fakultas Ekonomi Universitas Samudra.

Danim, Sudarman. 2017. Perkembangan Peserta Didik. Bandung: Penerbit Alfabeta.

Hartinah, Sri. 2014. Metode Penelitian Perpustakaan. Universitas Terbuka Tangerang.

Ismunandar. 2019. Pidato Ilmiah Dies Natalis 
XXXV/Lustrum ke - VII Insititut Seni Indonesia. Yogyakarta 29 Mei 2019. Yogyakarta. Yogyakarta: Insititut Seni Indonesia Yogyakarta.

Novianti, Tria. 2016. Pengaruh Prestasi Akademik Mata Pelajaran PAI Terhadap Minat Studi Lanjut Ke Perguruan Tinggi Agama Islam bagi Siswa MAN Pemalang Tahun Pelajaran 20152016. Pemalang: UMP.

Jamaluddin. 2014. Pengaruh Pemanfaatan Layanan Perpustakaan Terhadap Prestasi Belajar Mahasiswa di Universitas Hasanuddin. UPT Perpustakaan Universitas Hasanuddin. Makasar: UNHAS.

Moleong, Lexy J. 2017. Metodologi Penelitian Kualitatif, Edisi Revisi. Bandung: Remaja Rosdakarya.

ISI Yogyakarta. 2019. Pidato dan Laporan Rektor Pada Dies Natalis XXXV Insititut Seni Indonesia Yogyakarta 29 Mei 2019. Yogyakarta: ISI
Yogyakarta.

Arikunto, Suharsimi. 1998. Prosedur Penelitian Suatu Pendekatan Praktek. Jakarta: Rineka Cipta.

Sitiaisiyah dan Noorbaity. 2011. Pengaruh Pemanfaatan Perpustakaan Jurusan Teknik Sipil Terhadap Prestasi Belajar Mahasiswa Jurusan Teknik Sipil. Jakarta: Jurusan Teknik Sipil Politeknik Negeri Jakarta.

Perpustakaan Nasional. 2007. Undang-undang Perpustakaan No.43 Tahun 2007 tentang Perpustakaan. Jakarta: Perpustakaan Nasional RI.

Perpustakaan Nasional RI. 2013. Revisi Pedoman Pengelolaan Koleksi Perpustakaan Perguruan Tinggi. Jakarta: Perpustakaan Nasional RI.

Qalyubi, Syihabudin, dkk. 2017. Dasar-dasar Ilmu Perpustakaan dan Informasi. Yogyakarta: Jurusan IPI Fakultas Adab UIN Yogyakarta. 